\title{
EXPERIMENTAL STUDIES ON THE INFLUENCE OF TEMPERATURE TO THE POSTMORTEM CHANGES OF THE INNER EAR
}

By

\author{
N. TAKIZAWA
}

\section{From the Department of Oto-Rhino-Laryngology. Nippon Medical School}

(Director: Prof. T. Daito)

The author made investigation on postmortem change depend on the temperture in the inner ear by Daito's inner ear irrigating fixation method with three ways that were $5{ }^{\circ} \mathrm{C}, 15^{\circ} \mathrm{C}$ and $30^{\circ} \mathrm{C}$ in rabbits.

The results were as follows.

1) $5^{\circ} \mathrm{C}$ after death. The hair cells showed no marked change in 6 hours, and were showed atrophic, slender and contained pycnotic nuclei from 12 hours after death. There showed no marked change in the stria vascularis and the supporting cells after 24 hours on postmortem specimen.

The nuclei of the spinal ganglion cells showed no marked change till 6 hours after death, and were atrophic, slender and cotained pycnotic nuclei from 12 hours after death.

The vestibule and the semicircular canal showed no marked change till 6 hours after death.

2) ${ }^{1} 5^{\circ} \mathrm{C}$ after death. The hair cells showed no marked change in 3 hours, and tended to deterio* Tate from 6 hours after death. The supporting cells showed no marked change after 24 hours, while the stria vascularis tended to deteriolate from 12 hours after death.

The nuclei of the spinal ganglion cells showed no marked change till 2 hours after death, and all nuclei became atrophic and slender after 6 hours.

The vestibule and the semieircular canal showed no marked change till 6 hours after death.

3) $30^{\circ} \mathrm{C}$ after death. The hair cells showed no marked change in 1 hour, and marked change from 3 hours, and tended to deteriolate from 12 hours. The supporting cells tended to deteriolate from 6 hours, while the siria vascularis tended to deteriolate from 3 hours.

The nuclei of the spinal ganglion cells showed marked change after 1 hour, tended to derteriolate from 2 hours.

The vestibule and the semicircular canal showed no change till 2 hours, and showed loosening of the epithelium after 3 hours.

4) In $5^{\circ} \mathrm{C}$ after death the specimen showed no marked postmortem change histologically after 6 hours. The state at $15^{\circ} \mathrm{C}$ and $30^{\circ} \mathrm{C}$ corresponds to that respectively after 3 hours and 1 hours.

\section{温度の内耳死後変化に及ぼす影響に関する実験的研究}

日本医科大学耳舅咽喉料教室（主任：大藤饭三教授）

助手 潼沢伸行

I 緒 霉

1910 年初めて队耳死後变化に 関する先験的研究が偶 タ東酉同時に発表された。即ち本邦の冨田1，欧洲に沶
ける Nager 及び吉井2)によつてら゙ある、以来多くの人 の業續が続々と出たが，その成果は必ずしも満足すべき あのでなく，核心に触れるようなるのはなかつた。 
その原因怡結局固定法の不倩にあり，死後变化々固定 変化が入りまじつてはいか炕慧眼の土と踓るこれを見分 けることは不可能であつた。

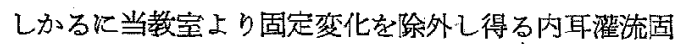

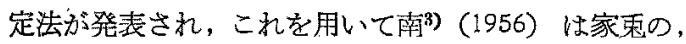

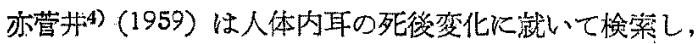
新知見を発表した。

しかしながらこれらの死後変化に関しては，経過した 時間の他，㞔体の置かれていた所の温度が問題になるこ とは当然楛党られる.何となれれば死後变化は即ち組織の 自家融解である以上この病理変化は温度に左右されるこ とは贅言を要さない。

これに関して松方5)(1918) はモルモット㡾を2匹宛 $1^{\circ}, 27^{\circ}, 37^{\circ} \mathrm{C}$ 亿夫々 5 時間放㯰して, 温度の高い程死 後の変化は㩆著でしか子尖端迴転上り，も基底回転の方に 颃いて甚しいといら。

Werner ${ }^{6}$ (1934)に上和ば人㞔を $1^{\circ}, 10^{\circ}, 27^{\circ}, 37^{\circ} \mathrm{C}$ 飞 15 時間保存する时は温度の低い程死後变化は少いと い5，近くは藤原7〕（1953）方モルモットを用い，20

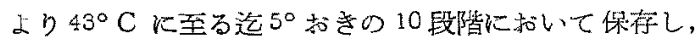

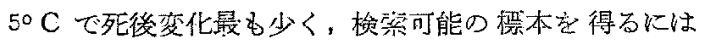
$23^{\circ} \mathrm{C} 1$ 時問, $18^{\circ} \mathrm{C} 2$ 時間, $13^{\circ} \mathrm{C} 6$ 時間, $5^{\circ} \mathrm{C} 12$ 時 間, $2^{\circ} \sim 8^{\circ} \mathrm{C}$ 6〜12 㭙間迄であるとしている.次いで 酒节:9)(1957) は内耳細胞の生存性に凯いて実駼を行い，

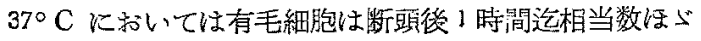

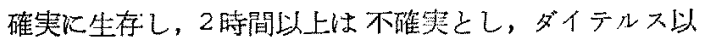
下の支持細胞は3〜5時間生存しているものといら，

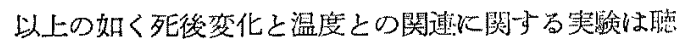

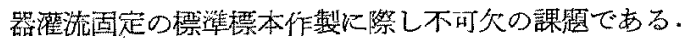

そこで私は四季の温度を勘案し， $5^{\circ}, 15^{\circ}, 30^{\circ} \mathrm{C} の 3$

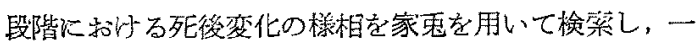
定の成續を得たのでこつに報告する。

\section{II 実験方法}

実験動物には家哥を用い，外耳道立に鼓膜に異常のな

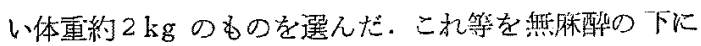
突然断頭し, 頭部范 $5^{\circ} \mathrm{C}$ 水室。(電気冷蔵植), $15^{\circ} \mathrm{C}$ 恒 温室, $30^{\circ} \mathrm{C}$ 蔇卵器讪炕之放犆して, 死後 $1,2,3,6$, 12, 24 時間後に側頭骨を取り出し，内耳灌流固定法を施 乙，法の如く後固定，脱灰，ツェロイヂン包埋，薄切の 後、へマトキシリン,エオヂン重染色を行つて推察し た。

\section{III 実験成鈢}

1) 死後 1 時間
動物雷:

$41 ， 46$ 号 (15० C k放置)

$4,5,14,15$ 号 (30 $\mathrm{C}$ に放監)

組織学的所見:

内・外リンパ腔：清澄。

前庭膜：核は長棈円形に涨染し異常はない。

血管条：全例之も暴常高認めない。

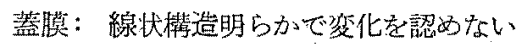

ラセン器： $5^{\circ} .15^{\circ}$ の手のと和いては内・外有毛細?

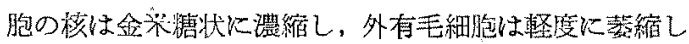
て細胞間に間隐をつくつている・ダイテルス，ヘンゼ ン,クラウデュース細胞の原形質は淡旷で，影粒状斿至

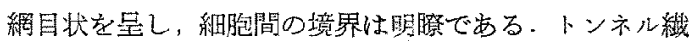

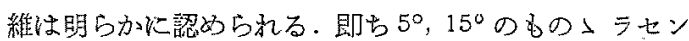
器は生体固定像と全く同じである: $30^{\circ}$ のものでは大部 分世上部と同様であるが，一部に外有毛細胞萎縮せず， その核子正円形淡染するるのが見られた。しか人内有毛 細胞，支持細胞には变化はない。

ラ七ン神経節 細胞： $5^{\circ}$ １50のものには变化が認好 られない.300のもので忹一部の校が濃縮し胞体も少し 装縮して周囲汇空吵るくつている。

前莛・半䙺管：平衡班及び膨大部稜の 有毛細胞の核 は濃縮して正常像を示し，支特細胞その他纪著变はな。 い.

前庭神経節細胞：買常はない。

2) 死後 2 時問

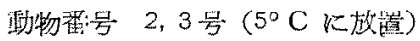

$$
\begin{aligned}
& 42,47 \text { 号 (150 C k放置) } \\
& \text { 7, } 36 \text { 号 }\left(30^{\circ} \mathrm{C}\right. \text { 江放置) }
\end{aligned}
$$

組織学的所見:

内・外リンパ腔：清澄.

前这膜：一般に变化なく，36号つ及校が膨大淡染し ている。

血管条：50，150のものでは異常を認めないが，300 の6ので恃皮稩胞の核が濃篗しているのが少し見られ た.

蓋膜：変化なし。

ラセン器： 50,150のものには変化がないが，300の ものでは有毛細胞の核は正形汇焁染し，胞体も生固像 の如く少し萎縮寸るるのもあるが，一般には浸漬固定像 の如くフックラとして萿縮していない，しかし支持細胞 には著変はない。

ラセン神経節細胞：50のものに変化なく, $15 \circ$ の。 
のには核の濃縮するものが少し認められる、300のもの では染色性の低下，核の濃縮，空隌形成（胞体の琵縮に よる）が見られた。

前庭・半規管：一般に著変はないが，有毛細胞の核 の淟縮しないものもかなり見受けられた。

前庭神経節細胞：異常を認めない。

3) 死後 3 時間

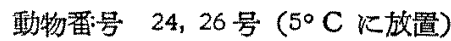
40,48 号 (15 $5^{\circ} \mathrm{C}$ k放置) $16,18,43$ 号 ( $5^{\circ} \mathrm{C}$ 放置)

組織学的所見:

内・外リンパ腔：清澄.

前庭膜：50のものでは核は長榾円形に清染し 異常な

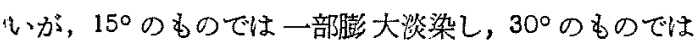
全て膨大淡染している.

血管条： $5^{\circ} .15^{\circ}$ のむのには変化を認め琼いが，300 のものでは上皮細胞の結合ゆる及崩壊に傾き一部の核は 濃縮している。

蓋膜：变化なし．

ラセン器：50のものは全く变化がないが，150のも の〉一部の有毛細胞の核は正円形淡染している。30の ものでは外有毛細胞は支柱斯上り離れ，円形に近づき， 核は点状 (小円形) 飞萎縮し，内有毛細胞は浮き上つ て，乥の核忹正形に淡染している。しかし支持細胞に 奻著変なく，唯クラウデニース細胞の一部が崩錘しかけ ている.トンネル繊維は消失している。

ラセン神経節細胞： $5^{\circ}$ のものに変化なく，150のる のでは䅭が濃縮するもの半数，300のものでは全て濃維 乙，且染色性の低下，胞体周围の空隚形成が見られる。

前庭・半規管： $5^{\circ}$ 及び $15^{\circ}$ のものでは变化なく, $30^{\circ}$ のものでは平衡斑及び膨大部稜の上皮層は剝離し，崩㯖 に傾き一部の支持細胞の核は濃縮し有毛細胞の核之区別 ができなくなつている。

前庭神経節細胞： $5^{\circ} .15^{\circ}$ のものに変化はないが， .300のものでは虎班融解起り，一部の核は濃縮してい る。

4) 死後6時間

動物番号 $30,31,34$ 号 ( $5^{\circ} \mathrm{C}$ に放医)

37,45 号 ( $15^{\circ} \mathrm{C}$ 火放置)

$8,9,19,21$ 号 (30 $\mathrm{C}$ 江放置)

組織学的所見:

内外リンパ腔： $5^{\circ}, 15^{\circ}$ のものでは清澄. $30^{\circ}$ のもの では血管条附近に Amorphmasse 見る。
前庭膜： $5^{\circ}, 15^{\circ}$ のものでは膨大淡染する核を有し， 30॰のものでは点状に萎縮や小濃染している.

血管条：50，150のものに殆んど変化を見ないが，300 の子のでは上皮層が基底上り剶離し，崩㯖傾き，染色 性の低下之核の濃縮が見られる。

蓋膜： $5^{\circ}, 15^{\circ}$ のものに变化を認めないが, $30^{\circ}$ のむ のではラセン緑との附着部が離れている。

ラセン緑：上皮緗胞の一部には核浀縮が見られる。

ラセン器： 50 のものは有毛細胞の核が 濃縮し，胞体 も軽度の䔉縮示すものが多いが，一部は核が正円形炎 染し，胞体石萎縮していない，支持細胞に変化はない， $15^{\circ}$ のものでは外有毛細胞の輆は正円形竾染し，胞体は 一部円形に近ずき配列か乱れている。しかし第 1 呾転始 部に挆いては有毛細胞の核は金米糖状に濃縮し，胞体も 朝度の萎縮を示し，トンネル 㵶維も明らが認められ る、支持細胞は全て变化を見ない，300のものでは有毛

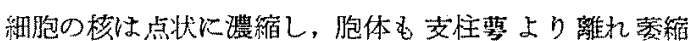
し, 配列が乱れている. 支持細胞は膨化し, クラウデニ 一ス細胞は崩壊に傾いている。

ラセン神経節細胞：50，150のものでは核が源縮し，

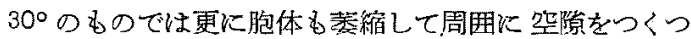
ている。

前庭・半規管： $5 \circ, 15^{\circ}$ のものでは平衡斑, 膨大部棱 の有毛細胞の核江濃縮しているが，膨大部棱の支持細胞

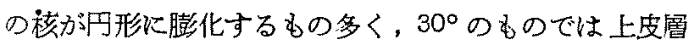

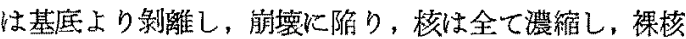
を多く見る。

前庭神経䬣細胞： $5^{\circ}, 15^{\circ}$ の bのに变化を認めない が、300のものでは核の濃縮をかなり見受ける。

5) 死後 12 時間

動物番: 号 $29,32,33$ 号 ( $5^{\circ} \mathrm{C}$ 江放置)

$$
\begin{aligned}
& 38,28 \text { 号 ( } 15^{\circ} \mathrm{C} \text { に放置) } \\
& 10 ， 11 ， 20 \text { 号 }\left(30^{\circ} \mathrm{C} \text { に放置 }\right)
\end{aligned}
$$

組織学学的所見:

内・外リソパ腔： $30^{\circ}$ のむの〉血管条附近に上皮細 胞の崩罣物を少し認奶る.

前㛹膜：5゚, $15 \circ$ のものでは膨大淡染する核を認め， $30^{\circ}$ のむのでは大部分点状菜縮, や入澧染している.

血管条： $5^{\circ}$ のものに变化なく, $15^{\circ}$ のむのでは上皮 㬝には全般に著变はないが, 所々一二の細胞の 結合緩 み，その核性濃縮している。300のものでは核の濃縮甚 しく, 上皮細胞は膨化解離し，崩墁した細胞が内リンパ 腔に逸出している。 
蓋脱： $5^{\circ}, 15^{\circ}$ のものに变化なく，300のものでは セン縁との結合が離れて線状棈造が幾分不明䐲となつて いろ.

ラセン緑：上皮細胞及びその下の結合組織では核濃 縮が篮められる。

ラセン器: $5^{\circ}$ のむのでは外有毛細胞の䄯は正円形资 染し，胞体は短維して方方形に近ずき，支柱要さり離れ ている.内有毛維胞は膨化して跳上り核が正师形淡染し ている．支持細胞には変化がない，トンネル繊維は諗め

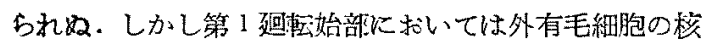
はや>濃縮し形当整い，トンネル瀻維も明らかに認めら れる.150のもので外有毛細胞は立方形必は円形とな り，配列は乱れ，内有毛細胞憉化し跳上つている. 核 は全て正円形染染している.支持細胞には㱠えど变化が ないが内ラセン溝細胞の一部の校が濃縮している。しか して第1迴転始部においては外有毛細胞の核は点状に濃

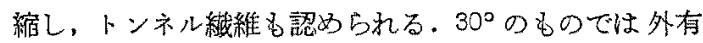

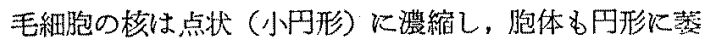

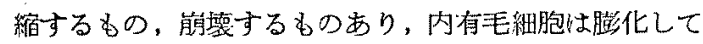
いる. 交持細胞も颤化し，配列乱れ，境界不明膫となつ ている、特にクラウデニース細胞は崩壊し，ペッチェル 細胞に核濃縮を見る。第 1 建蒜绐部に和いては幾分変化 の度は少いが，トンネル縅維はもはや認るられない。

ラセン神経節綥胞：核は全て濃緶しているが，胞体

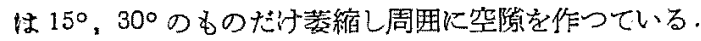
特に 30の6のでは染色性が甚だしく低下し翌化がひど W.

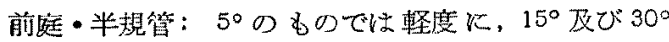
のbのでは高度に有毛細胞の核が点状に濃縮し，支持細 胞の㯖は膨化淡染している。

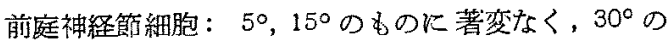
ものでは染色性が但下し，一部の核が濃縮し，胞体も少 し萎縮している。

6) 死後 24 時間

動物置号 25,35 号 (50 C K放置)

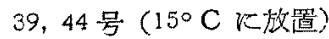
$12,17,22$ 号 $\left(30^{\circ} \mathrm{C}\right.$ に放睓)

組䋨学的所見:

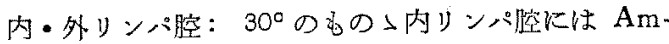
orphmasse 多く認める。

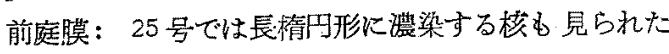
が，一般に $5^{\circ}, 15^{\circ}$ の子のは膨大淡染する核を有し，30 のわのでは核の染色性甚しく低下して小さく菱縮し, 膜
そのものも菲薄となる。

血管条：50のbのに異常なく，150のbのでは核は

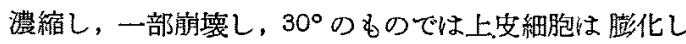

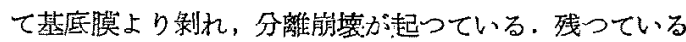
核は全て曟縮し，一部崩徒に陮つている。

盖脱： $5^{\circ}$ のものに変化なく，150のものでは39号の みラセン縁との附着部が剝れかけ，300のbのではこれ が完全に離れ，膨化して形を变点ている。

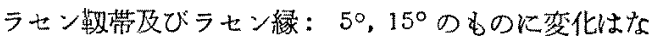

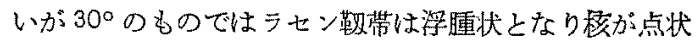
に濃縮している，ラセン緑は染色性甚だ低下し垽胞形成

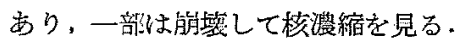

ラセン器：50のものでは外有毛細胞は円形になり， 配列乱れ，核は点状に濃縮している。内有毛細胞は膨化 して核は正円形焱染している，支持細胞には殆えど变化 がない.トンネル瀻維は認められないが，第1廹枟始部 においては残存している. $15^{\circ}$ のものでは外有毛細胞の

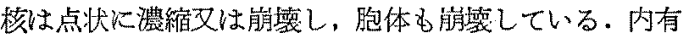

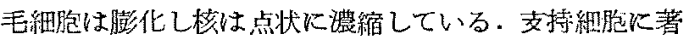

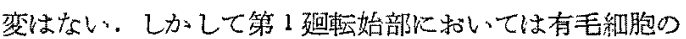
班は整い、トンネル瀻維が認められる。300のるのでは 有毛細胞は崩壞飛散しているが，点状に澧縮与る核を持 つ細胞は末だ目位置附近に少し認められる。ダイテルス 細胞を初め支持細胞は殆えど崩塔消失しているが，ヘン ゼン細胞の一部がペッチエル細胞と共に残つている。 内，外柱怯異常ない，乙か乙第1 迴転始部では絊分形が 整づいる。

ラセン神経節細胞：核は全て濃縮し，150のbので は胞体む業縮し，300のもので、にが甚しく，染色性 低下している。

前庭・半規管： $5^{\circ}, 15^{\circ}$ のものでは平衡斑，趁大部棱

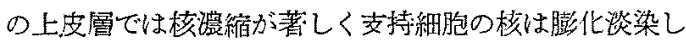

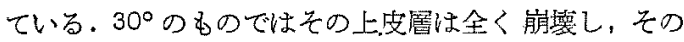
残渣物中心高度以濃縮した裸核及び磷子様球を認める。

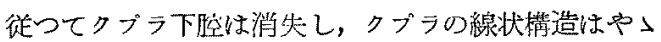
页明嘹上なつている。

前庭神経節細肥：5006のでは僅かに移溰縮が見ら

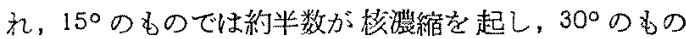

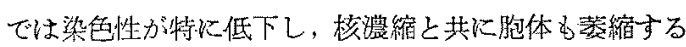

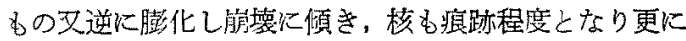
一部は融解消失している。

\section{IV 紷括並に考按}

以上の成縝を総括すれば 


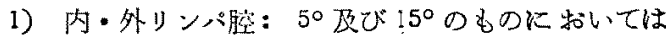
死後 24 時间に至る。清澄. $30^{\circ}$ のものに和いては 3 時

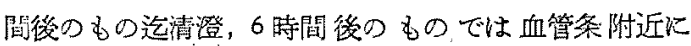
Amorphmasse 证見，12 時間以後》ものでは上細胞

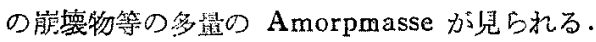

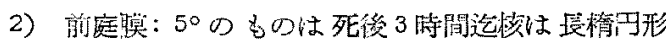

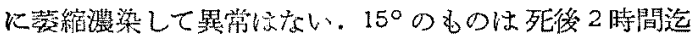
巽常なく、3脚间のものでは一部の核の膨大淡染するの

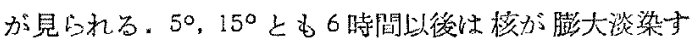
るだけで望变はない，300のものは死後 2 時間でずで 約半数の核の膨大淡染するのが見られ，死後 3 時間では 全部の核が膨大淡染する.6時間以後のるのでは棎は点 状涹縮し，や小濃染する，24 時間後になる上核の染

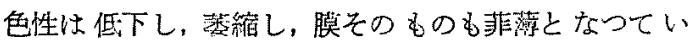
る.

3）血管条：50のものでは死後 24 时間に至るむ異 尝は見ら机ず，150のものに和いては死後6 時問迄異常 なく，12 時間後火至つて上皮闻の一二の稩胞の絬合が ゆるみ，核心濃縮している，24時間後で核は旗縮し， 一部は崩堎している. $30^{\circ}$ のものでは死後 2 時間で一部

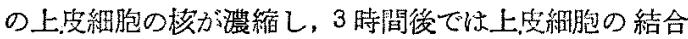
がゆるみ，崩壊に傾き，一部の核仙漲縮している。6時 間後では上皮圈が基底上り剝離し，崩壊に傾き，染色性 は低下し，核は灙縮している１2時間以後においては

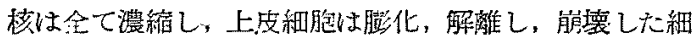
胞が内リンパ腔に逸出している。

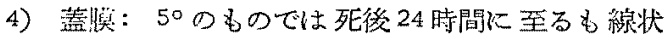
赫造明らかで变化はない. $15^{\circ} の$ むのでは死後 12 㭙間 迄は変化なく，24時間後のるのでは一部ラセン縁との 附萿部が離机ている. $30^{\circ}$ のむのでは死後 3 時間迄变化 なく、6 時間後のものではラセン縁との附着部が 離れて いる. 12 時間後のものでは線状棈造が 幾分 不明膫とな り，24 時間後汇至つてはラセン縁との附着部が 㫕全に 離れ，瞦化して形を恋えている。

5) ラセン器：

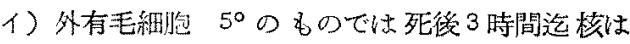

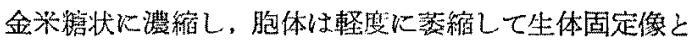
全く同じで変化を見ない，6時間後では一部の刻怔正円 形淡染し，胞体も坡縮せず，12 時間後では核は全て正 円形火淡染し，咆体は短縮して立方形伈近ずき支柱舆よ り離れている，24時閵後に至つては細胞は円形となり， 配列は乱れ，核は点状に溧縮している。

$15^{\circ}$ のもので壮死後 2 時間迄は变化なく, 3 時間後の
ものでは一部の䅭が正円形に淡染している。6時間後の ものでは核は正円形に淡染し，胞体は一部门形に近ず き，配列が乱れている.12時間後つものでは胞体は立。 方形又は円形となり，配列の乱れは更に强くなつてい る。しかし第1廻転始部においては未た核は㹂縮し，胞 体も軽度の荌縮を示しているのが認められる. 死後 24 時間に至つては核は点状に濃縮又は崩噩し，胞体も崩䏅 している。

300 のるのでは死後 1 時間では大部分变化なく，一部 に胞体が菱縮せず，核も正円形に淡染しているものもあ る. 2 時間後のものでは核は正円形に淡染し，胞体は一 般にフックラとして䔉縮せず，3時間後のるのでは胞体 は円形们近ずき，支柱警より離れ，核注点状（小円形）

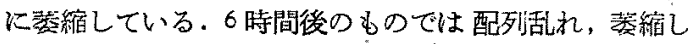

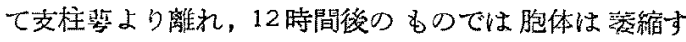
るもの, 文崩壤するものあり，死後 24 時間に 至ると細

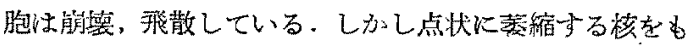
つた細胞は未だ旧位置附近に少し認められる。

口）内有毛細胞 50 の bのでは死後 3 㭙间迄梳 化なく，6時閒後のものでは一部の核は正円形に淡染 し，胞体妇荌縮せず 12 時間及び 24 時間後つるのでは 核は正円形淡染し，胞体は膨化して跳上つている。

$15^{\circ}$ のものでは死後 2 時間迄变化なく3㭙間及び6 時間後のものでは一部の核は正円形に淡染している１2 時間後のものでは核は全て正円形に淡染し，胞体は膨化 して跳上つている. 24 時間後のものでは胞体は膨化し， 核柱点状汇漫縮している。

300 のものでは死後!時間は变化はてい，2時品後の ものでは核は正円形淡染し，胞体わ少し萎縮するもの もあるが一般にフックラとして萎縮せず．3时間後のも のでは有毛細胞は浮き上つて，その核は正円形に淡染し ている.6時間後のものでは核は点状に萎縮し，胞体も 交柱萝上り鼠れ，苳縮して配列が乱れている，12時間 後のものでは胞体は膨化しておう，24時間後つもので は完全に崩壊飛散している.

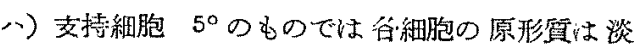
明で顆粒状了至網目状を呈し，細胞間の境界は明盼で死 後 24 時間に至名る殆んど変化を見ない，

$15^{\circ}$ のものでは死後 6 時間迄恔变化はない，死佟12時 間のものでも砝んど变化はないが，内ラセン满緗胞の一 部の核が湢縮している。死後 24 時間に至つても著变は ない.

$30^{\circ}$ のものでは死後 3 時間迄は変化はない， 
第 1 表 $\left(5^{\circ} \mathrm{C}\right.$ のめ)

\begin{tabular}{|c|c|c|c|c|c|c|}
\hline 部 位 & 1 & 2 & 3 & 6 & 12 & 24 \\
\hline 内・外りンパ腔 & - & - & - & - & - & - \\
\hline 前庭膜 & - & - & 一 & + & + & + \\
\hline 血＼cjkstart管 & - & - & - & - & - & - \\
\hline 蓋 ：膜 & - & - & - & - & - & - \\
\hline ラ(外有毛細胞 & - & - & 一 & + & $t+$ & H \\
\hline 七们有毛細胞 & - & - & - & + & $H$ & $H$ \\
\hline ン支持 細 胞 & - & - & - & - & - & - \\
\hline 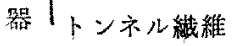 & - & - & - & - & $t$ & + \\
\hline ラセン神経節細胞 & - & - & - & + & $H$ & $H$ \\
\hline 前 庭一半 規 管 & - & - & - & + & H & H \\
\hline 前庭神経 節細 胞 & - & - & - & - & - & - \\
\hline
\end{tabular}

第 2 表 $\left(15^{\circ} \mathrm{C}\right.$ の の)

\begin{tabular}{|c|c|c|c|c|c|c|}
\hline 部 位 間 & 1 & 2 & 3 & 6 & 12 & 24 \\
\hline 内・外yンパ腔 & 一 & - & - & - & - & - \\
\hline 跮 & - & - & + & + & + & + \\
\hline 血 & - & - & - & - & $H$ & $H^{4}$ \\
\hline 蓋 & 一 & - & - & - & 一 & + \\
\hline ラ 外有毛細胞 & - & - & + & $H$ & $H$ & HAt \\
\hline 七众有毛細胞 & - & - & + & + & $H$ & tt \\
\hline ン支持 細 胞 & $\rightarrow$ & - & - & - & + & + \\
\hline 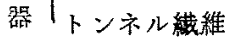 & - & 一 & - & + & + & $H$ \\
\hline ラセン神経節細胞 & - & 一 & + & + & $H$ & $H$ \\
\hline 前庭 - 半規管 & - & - & - & + & $H$ & $H$ \\
\hline 前庭神経節 細 胞 & - & - & - & - & - & + \\
\hline
\end{tabular}

第3表 $\left(30^{\circ} \mathrm{C}\right.$ のの)

\begin{tabular}{|c|c|c|c|c|c|c|}
\hline 部 位 時 & 1 & 2 & 3 & 6 & 12 & 24 \\
\hline 内・外りンヘ腔 & - & - & 一 & + & + & $H$ \\
\hline 庭 & - & + & $H$ & $H$ & $H$ & HH \\
\hline ，管 & - & + & $\mathrm{Ht}$ & H & H\# & 册 \\
\hline 苗 & - & - & - & $t$ & $H$ & $\mathrm{HH}$ \\
\hline ラ (外有毛細胞 & + & + & $H$ & H & 册 & 曲 \\
\hline 七」内有毛細胞 & - & + & $H$ & H & $\mathrm{HH}$ & itt \\
\hline ン支持細 胞 & - & - & - & $H$ & HH & 冊 \\
\hline 器 1トンネル緎維 & - & - & $H$ & $\mathrm{H}$ & Htt & Htt \\
\hline ラセン神経節細胞 & + & $H$ & $H$ & itt & HH & HAt \\
\hline 前 庭 - 半 規 管 & 一 & $H$ & H & $H$ & - & Hit \\
\hline 前庭神 経 維 細 胞 & 一 & 一 & + & $H$ & $H$ & H\# \\
\hline
\end{tabular}

(一) 变化なし (十) 軽度变化古り

(十) 中等

度変化あり

(H) 高度変化汸り

(H) 崩榩
死啳 6時間のものでは各細胞は膨化し，クラウデュー ス細胞は崩堙に傾いている. 死後 12 時間に琹つては膨 化は更に進双，配列は乱机，境界は不时暸となつてい る、特にクラウデユース絸胞は崩瀻しベッチェル細胞に 核濃縮を見る，24時間後のむのてはダイテルス維胞を

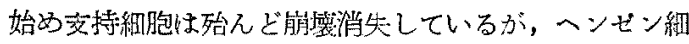
胞の一部がベッチエル細胞と其に残つているのが認めら れるた゚けである。

二トンネル瀻維 50 ○当のでは死啳6时間迄は

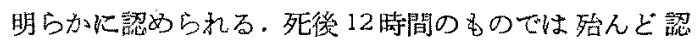

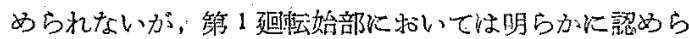

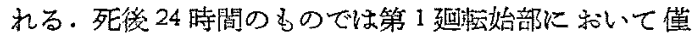
か残存している.

$15^{\circ}$ のbのでは死後 3 時問迨は明らかに認められる

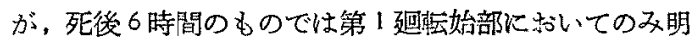
らかに認められる. 24 時間後のものでも第1自転始部に 扎いては明らかに残存している。

300のあのでは死後2 時間迄は明らかに認められる. 死後了時間以上程過したものては消失して放り，死後12

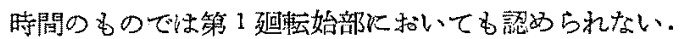

6). ラ七ン神経節細胞：50の8のでは死後3時間汽 翌化なく，6羘間後のものでは一部の稌が濃縮している. 12 㭙間後のものでは核は全て濃縮しており，24時間後 のものでは胞体も萎縮している。

$15^{\circ}$ のbのでは死後 1 時間の ものは変化なく，2 時間 後のbのでは核の縮㺜するすのが少し諗められる，3時 間挠のbのでは約半数の核が清縮し, 6 時間後のもので

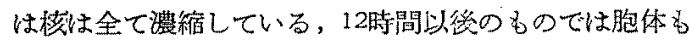
藋縮している。

30のものでは死後 1 時間ですでに一部の核は澧縮し，

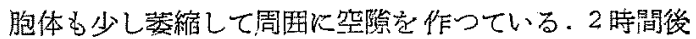

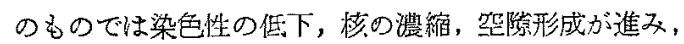
3時間以後のるのでは核休全て濃縮し，染色性は甚し? 低下する.12時閂以後のものでは変化が藗しく染色性 むいちじるしく但下している。

7) 前庭・半涀管：50のbのでは死得 3 時閏迄は平

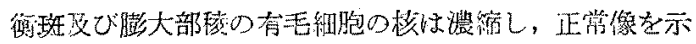

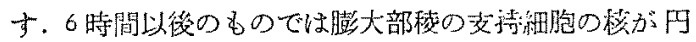

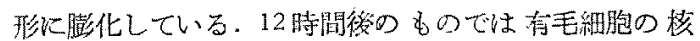

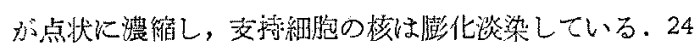

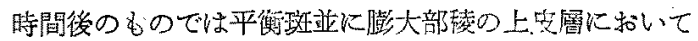
核の濃符甚しく，卖㘧細胞の核は膨化淡染している。

$15^{\circ}$ のbので心死隻了時間迄は变化はない.6時間後 
のものでは膨大部稜の支持細胞の核が円形に膨化し，12 時間後のものでは有毛維胞の核が高度に点状に婊縮し， 交持細胞の核憉化淡染している. 24 㭙間後のもので は平衡斑及び膨大部稜の上皮層の核濃縮甚しく，支持細 胞の核は膨化淡染している.

$30^{\circ}$ のものでは死後 1 時間のものは变化はない，2時 間後の\&のでは有毛細胞の核の濃縮しないるのか゚かなり 見られる。3時間後のbので平衝斑及び膨大部稜の上

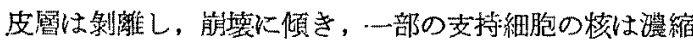
し，有毛細胞の核と区別ができなくなつている，6時間

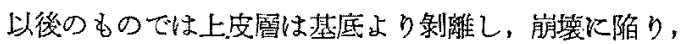
核は全て澧縮し，裸核を多く認める。24時間後の6の に至つては上皮買は全く崩壊し，高度に濃縮した裸核及 び硝子㴍球を認める. 従つてクプラ下腔は消失し,クプ ラの線状構造はや〉不明瞭となつている。

8) 前庭神経節細胞：50のものでは死後 12 時間迄 変化はない. 24 時間のbので俺かに核濃繀が見られた。

$15^{\circ}$ のものでは死後 12 時間迄变化なく24 時間後のb ので約半数の核濃縮が見られた。

$30^{\circ}$ の6のでは死䒺 2 时間迄は変化なく, 3 時間後の ものでは虎斑融解起り，一部の核は浱縮している．6時 間後のものでは核の濃綰はかなり見受けられる.12時 間後のものでは染色性は低下し核は濃縮し胞体も萎縮し ている. 24 時間後のものでは染色性が特に低下乙，核

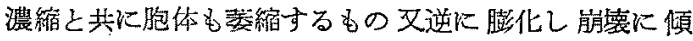
き，核む瘨跡程度となり更に一部融解消失している。

さて，上記の成績上先人のbのと比較して子上5。

ラセン器に就いては藤原す8)がモルモツトを用い，

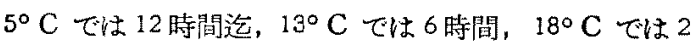
時間迄检䇣可能としている。そして $28^{\circ} \mathrm{C}$ 以上では 1 時間後で既に死後变化が明らかにあらわれ，正確な検采 は困難であるとしている。

従来の見解では㘯物の種類，大小で死後帘化の速度は 異るとされてはいるが，私の用いた家束ては上訶の如く $5^{\circ} \mathrm{C}$ では 6 時間迄生前の像に近いものであり，24 時間 後でも全ての支持細胞は变化なく㫿ふ有毛細胞の变形々 配列の乱れが見られた。 $15^{\circ} \mathrm{C} て ゙ は 3$ 時間迄生前に近 く，支持細胞は24时間後でも変化ないが，有毛細胞は 6 時間後で変化をきたし，12時間後ではこれが強くなり 配列方乱れてくる. $30^{\circ} \mathrm{C}$ では 1 時間後迄生前に近く， それ以後急激に变化をきたし，支持細胞は6時間後で既 に膨化し崩琝に傾く.

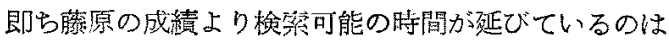

動物の䢮類による違いも少しはあららが，主として固定 法の優我に上るむのと思われる。私の用いた灌流固定法 は即座に一㥞に固定できるに反し，従来の浸漬固定では 固定変化が加わるからである.

しかして漫漬固定を行つた場合，Nager 及び吉井2) を初め中村登10)他多くの人は固定液は前庭・蝸牛两空 上り入る故，死後変化は基喽廷転上り先端迥転に向つて

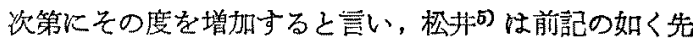
端迴転より基碐廼転の方に变化が甚しいとしているし，

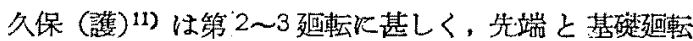
は固定液漫入に便なるため变化は少いとしている。

即ら死後変化とは言うもの上固定液の涾入の工合で变 ることを各著者とも認めているわけであるが，私の場合 は灌流固定であるためこの圆定差はないものと思われ ๖.

それにる拘らず第 1 延枟始部の变化は上方のものと较 ベて明らが数段少く，例えばトンネル瀻維に注目して みても，50 C のものは一般に6 時間後迄認められるの に第 1 迴転始部では24 時間後でも明らかに浔められる

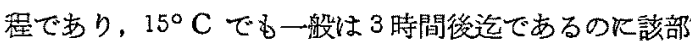
のみは24時閻後でも認められる。

このことは會つて久保11) 記載しているところで彼 は 48 時間後です基硬延回転の 始部の最始部においては恒 にトンネル絿維を認めたという．即らこの部の変化の度 が他较べて著しく軽いのは洵に奇妙なことである。

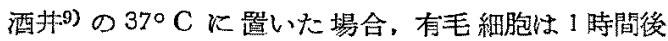
迄相当数ほ心゙確実に生存し，2 時間以上は不確実として いるが，私の实験でる $30^{\circ} \mathrm{C} て ゙ 1$ 時間後には大部分の

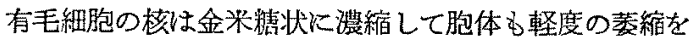
示してはいるが，一部に胞体が萎縮せず核も正円形桨染 し，正常組統の反応像を呈しなかつたことはこの一部の 当のたりが多少活力が落らてはいるが，大体生きている と見做してよいであるう．しかして2 時間後ですべて 檬は濃縮せず胞体もフックラとしており，3時間後ては

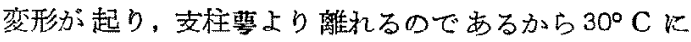
置かれた場合は 2〜3時問で細胞死が起るとみて差交党 ないであるら。

次火藤原78) は死後变化は温度が高い程速かである

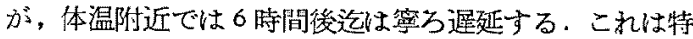
にラ七ン神経細胞に明らかにあらわれるとしているが， 蛋白分解の如き化学变化である死後变化が生前の体温に 保持された場合却つて遲延する。即ち $33^{\circ} \mathrm{C}$ が最もひ どく, $30^{\circ} \mathrm{C}$ で密ろ少いこいらのは何とす理解しがたい

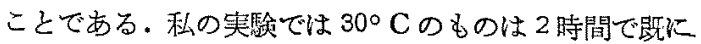


高度の変化があらわれるが，これが仮に家東の体温 $40^{\circ}$ C の所证置かれていたとした埸合，变化が 却つて少く なるとは到底考兄られない。

前庭・半規管の変化は従来ラセン器より軽いものとさ れていたが，構造の簡単，複雑の遠いでとの上うに見ら れがちではあるが，仔細に見るなら時間の経過と共に夫 々かなりの変化を現わし，変化の殆えどないのは $5^{\circ}, 15$ ${ }^{\circ} \mathrm{C}$ では 3 時間後迄， $30^{\circ} \mathrm{C}$ では 1 時間迄で時間的には ラセン器と同じ程度で，特に $30^{\circ} \mathrm{C}$ の場合 3 時間後で 上皮㬝が剝離し，葄壊に傾くことはラセン器の支持緗胞 が 3 時間後迄変化を見ないのに較べ注目すべきことであ る。

前庭神経節細胞はラセン神経節細胞に较べれば確かに 変化は少いが，この場合の固定状況の違いは夫々の位置 的関係からどうにもなら炕ことである。

ともあれ，内耳の死後变化は動物の種頪によつて多小 の違い怯あろらが，冬期 $5^{\circ} \mathrm{C}$ 附近の気温であれば死後 5 6 時間でも所謂純死後变化のない生前に 近い，標本が 得られるに反し，夏期 $30^{\circ} \mathrm{C}$ 前後の気温では死腾 2 時間 でも既火变化が現かれることは特記尗べきことで我々と しては標本採取に際しその時の状況を精しく調い゙ねね゙な らない.

\section{$\mathbf{V}$ 結 論}

温度の内耳死後变化に及ぼす影響を研究するため，家 束を用い，断頭後 $5^{\circ} ， 15^{\circ}, 30^{\circ} \mathrm{C}$ の環境に放置し，夫

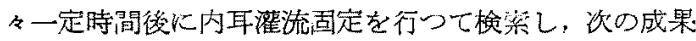
を得た。

i） $5^{\circ} \mathrm{C}$ のところに放置した場合には，有毛縕胞は 6

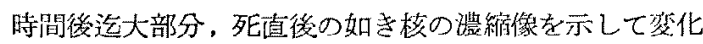
なく，12 時間後で変形が起る．支持縕胞，血管条及び 蓋膜は 24 時間後でも変化を認めない。

ラセン神経節 細胞は6時間迄著変なく、12 時間後で は核が澧缩する。

前庭・半规管盾6 時間後迄大した変化はない。

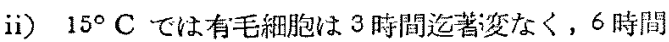
後で少し変形が起る.12 時閪後ではこ机が增強し，配 列が乱れている.支持細胞は24 時間後でも变化を見な いが，血管条は 12 時間以後, 次第に崩㯰への道を辿る。

ラセン神経節細胞は 2 時間迄著变なく，6時間後ては 全ての核が漕縮する。

前庭・半規管は 6 時間後迄㥩しい变化はない

iii) $30^{\circ} \mathrm{C}$ で,有毛細胞は 1 時間後迄著変なく，3浾 間後てはかなり変形が起り，12時間後で崩壊する.叒
持細胞も 6 時間後に膨化を認め崩墴に傾く，血管条怯 3 時间後で崩蕒し始める。

ラセン神経節細胞は死後 1 時間で既に 变化を示し， 2 時間㣪のるのでは染色性の低下，核濃縮を認める。

前庭・半规管で 2 時間後迄大した変化はないが，3 時間後では上皮層の刽離，崩壤が認められる。

iv） $5^{\circ} \mathrm{C}$ では 6 時間後でも所謂純死後变化は殆んど

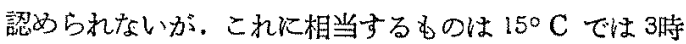
間後迄， $30^{\circ} \mathrm{C}$ では1時間後迄である.

\section{文献}

1) 富田：耳鼻臨床，4:234，1910。

2) Nager u.

Yoshii: Z. O. Heilk. 60:93, 1910

3) 南: 日耳 翼, 59 : 296, 1956.

4）菅井：日耳率，62：1525, 1959. 5) 松井：日耳鼻，24:725，1918。 6) Werner: Z. Hals u.s.w. H. K. $35,1934$. 7) 藤原 : 日耳奥，56: 54, u. $855,1953.8$ 8) 藤原：耳奥咽喉科 骎近の進步，山川著による，353，1956。9）酒井：日 耳渒，60:1367，1957.10) 中村登：日耳鬼，21： 591，1915. 11) 久保謢：福岡医誌，15：901，1922.

第1図: $15^{\circ} \mathrm{C}$, 死後 1 時間

\section{付图説明}

有毛細胞の核は嵈籍。胞体間飞腺間を生し，支持細胞 の原形質は淡明で顆粒状をなし, 生体固定像と全く同 一である。

第 2 図: $30^{\circ} \mathrm{C}$, 死後 1 時間

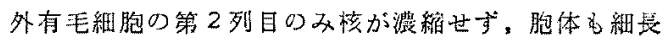
くなつていない，染色性低下す しかし一般に著しい 变化はない。

符 3 図： $15^{\circ} \mathrm{C}$, 死後 3 㖫間

内ラセン潎細胞の膨化の他殆ど変化ない。

第 4 四： $30^{\circ} \mathrm{C}$, 死後 3 時間

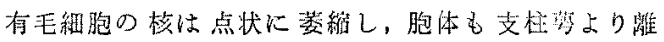
れ，円形に近ついている，支持細胞は膨化し，一部萠 壊㖽いている。

第5圆： $5^{\circ} \mathrm{C}$, 死侵6時間

第1图上同しく有毛細胞の核は浿縮し，殆ど变化を認 めない。

第 6 図： $30^{\circ} \mathrm{C}$, 死後 6 時間

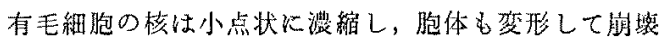
しかけている。支持細胞は一部崩䈠し，蓋膜もラセン 緑より影机ている。

第 7 図： $5^{\circ} \mathrm{C}$, 死㥅 12 時間

外有毛細胞の核は正円形淡染し，胞体は立方形に近ず 
き，内有毛細胞は跳上つている。しかし支持細胞に変 化はない.

籍 8 図： $15^{\circ} \mathrm{C}$ ，死後 12 時間

有毛細胞变形して配列乱九る他，支持紏胞に著変はな w.

第 9 图: $30^{\circ} \mathrm{C}$ ，死後 12 時間

有毛細胞は崩壊に㑯き，支持細胞む一部完全に崩境

し，蓋膜，血管条も基底上り䟝れている。

籍 10 因： $5^{\circ} \mathrm{C}$, 死後 24 時間

外有毛細胞は円形になり．配列乱れているが，支持細 胞に变化はない。

第11図： $15^{\circ} \mathrm{C}$, 死後 24 時間

有毛細胞は崩譬しているが，支持細胞に著変はない。

第 12 図： $30^{\circ} \mathrm{C}$ ，死後 24 時間

ラセン器は大部分崩滾して, 柱細胞とへンゼン細胞の

一部を残すのみ，血管条は槑れ，細胞は分㒕崩壤に陷 つている。

第 13 図: $5^{\circ} \mathrm{C}$, 死後 1 晧間 ラセン神経節細胞に变化は認めない。

第 14 图: $15^{\circ} \mathrm{C}$, 死後 3 洔間

ラセン神経節紐胞の約半数に核濃縮を見る。

第 15 図： $30^{\circ} \mathrm{C}$, 死後 12 時間
ラセン神経節細胞は萎縮して周囲に空隙をつくり，核 む全て濃䑿している。

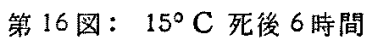

溦大部棱，支持細胞の核が円形に膨化．クブラ下腔に 多くの Amorphmasse 又化硝子様球を見る。

第 17 図： $30^{\circ} \mathrm{C}$, 死後 24 時問

上皮㬝は崩買し，濃縮した裸核やAmorphmasse 及 び硝子様球を多く見る。

第 18 图: $30^{\circ} \mathrm{C}$, 死後 24 時聞

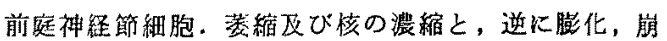

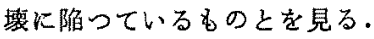

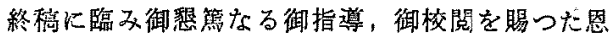
師大藤教授，野本講師に衰心より謝意を表し，僧せ て終始御叱正，御鹳墱を頂いた芳野助教授，下谷病 院内山院長，耳器咽喉科医長永井氾博士，北梹俊之 惟士に深謝致します

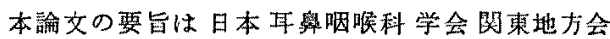
第369回大会で報告した。

(原副到着 $=$ 昭和 35.8 .31 日一急載) 
第 1 図

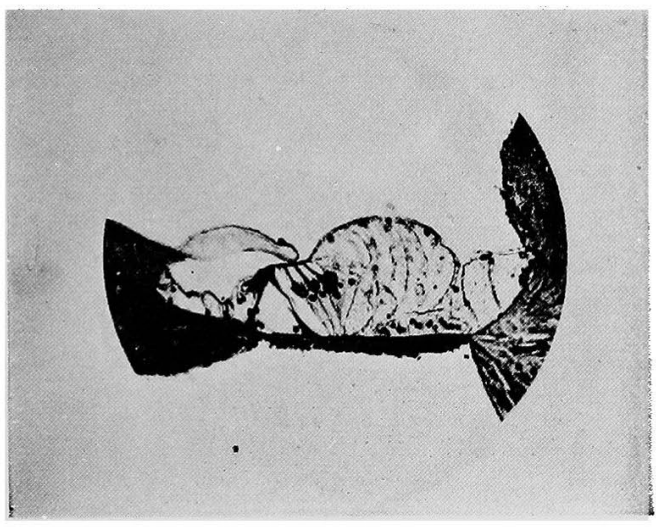

第 3 図

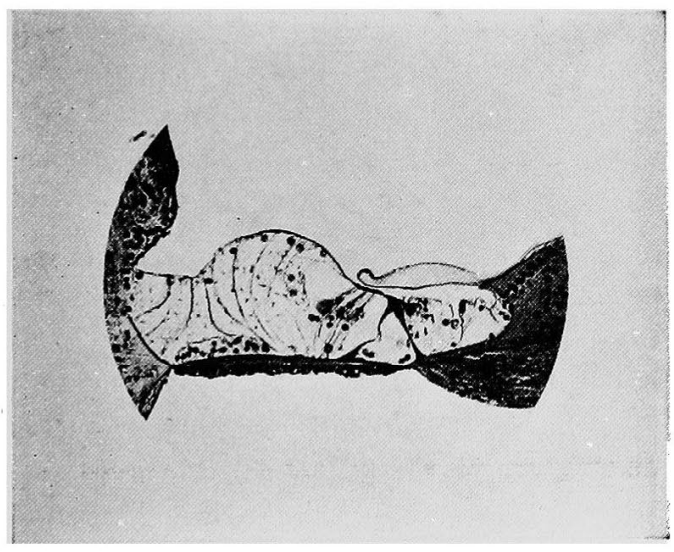

第 5 図

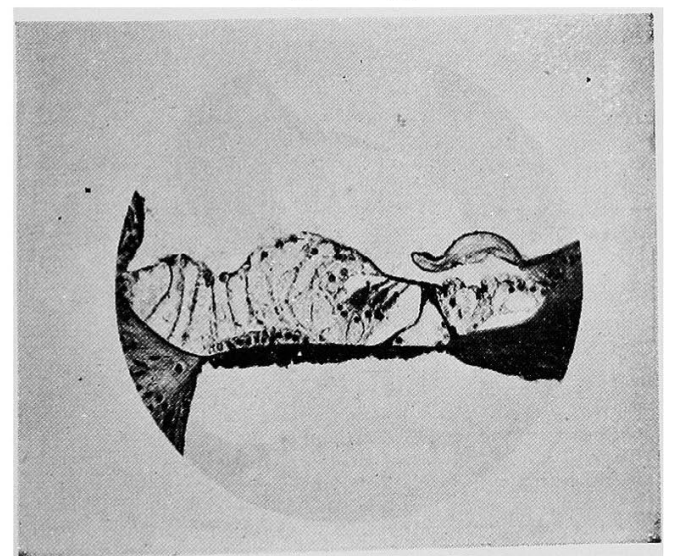

第 2 図

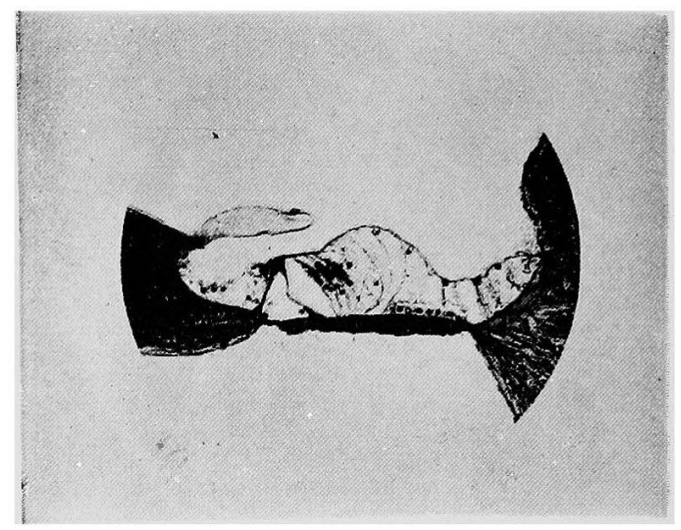

第 4 図

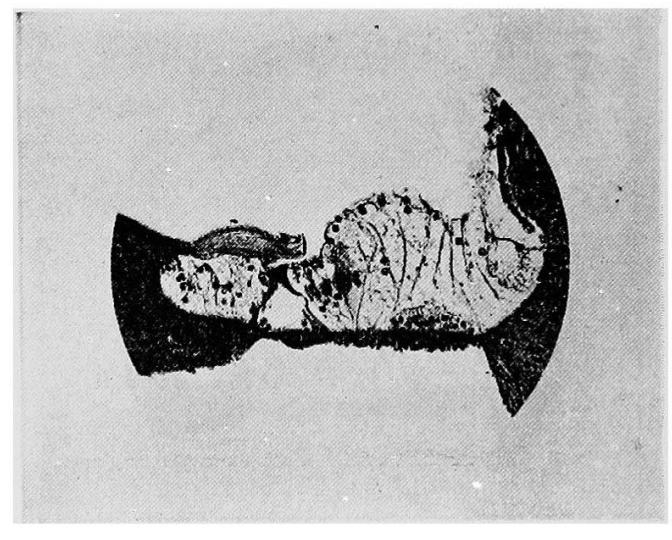

第 6 図

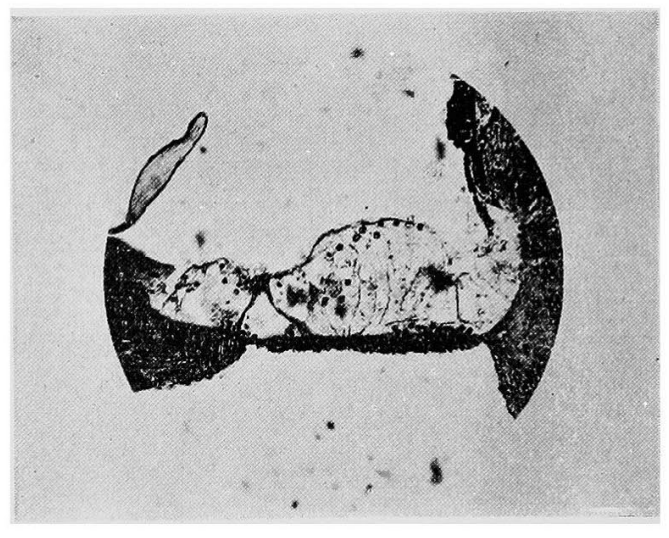


滝沢論交付図（I)

第 7 図

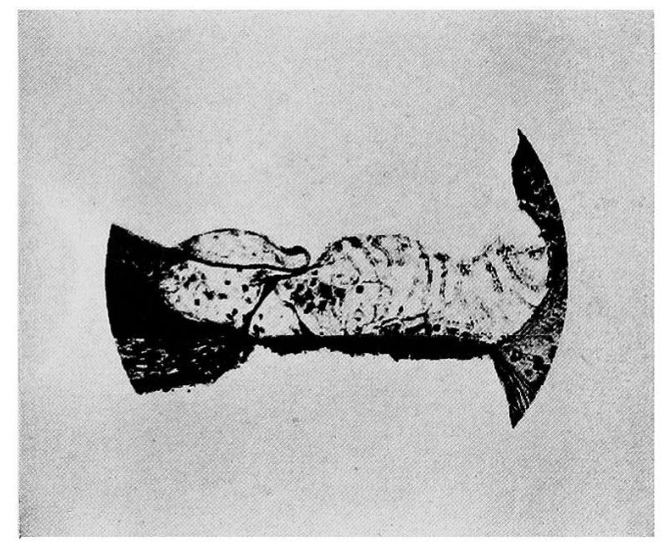

第 9 图

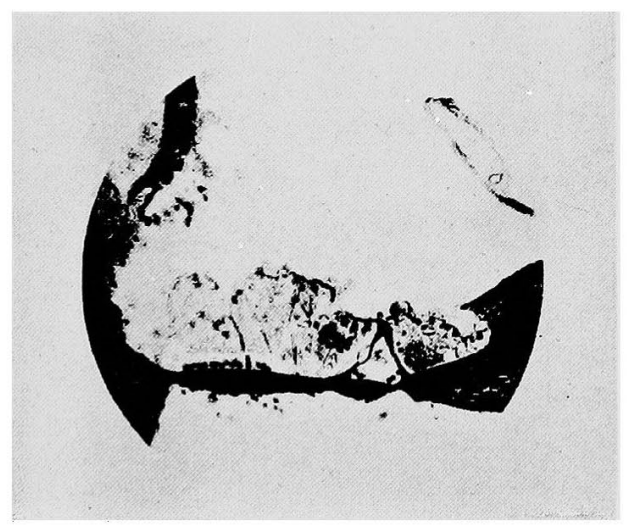

第 11 図

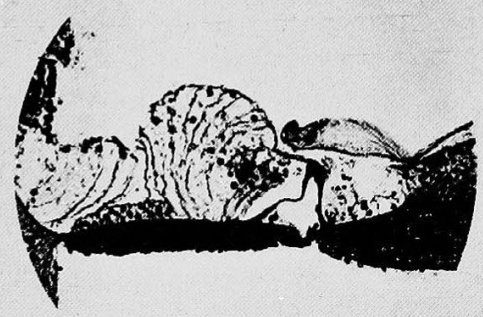

第 8 図

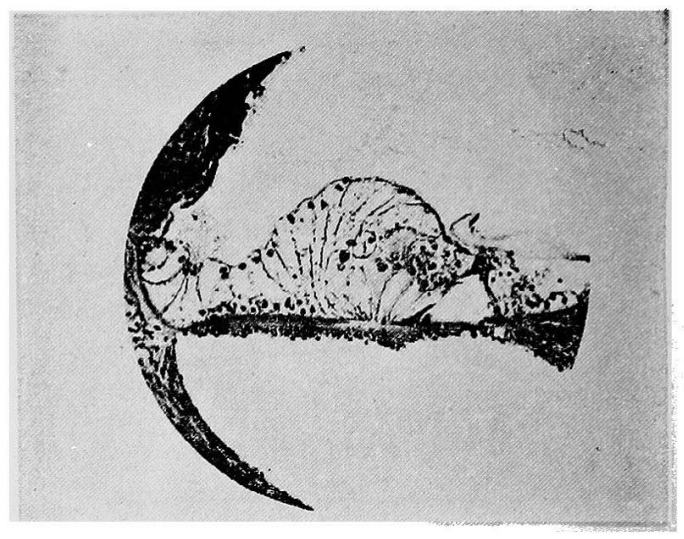

第 10 図

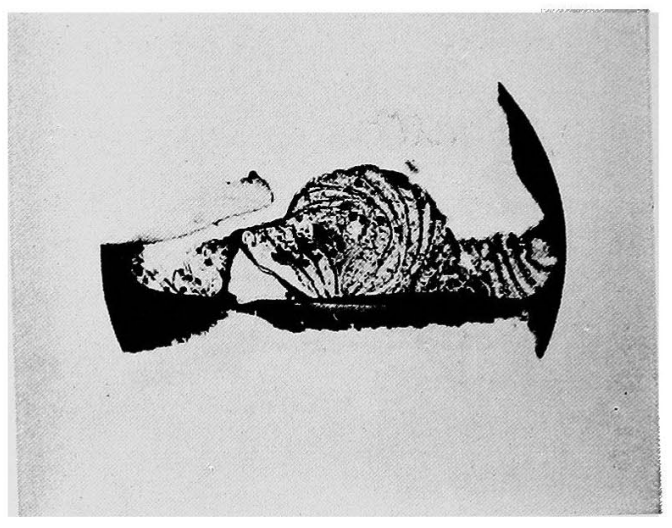

第 12 図

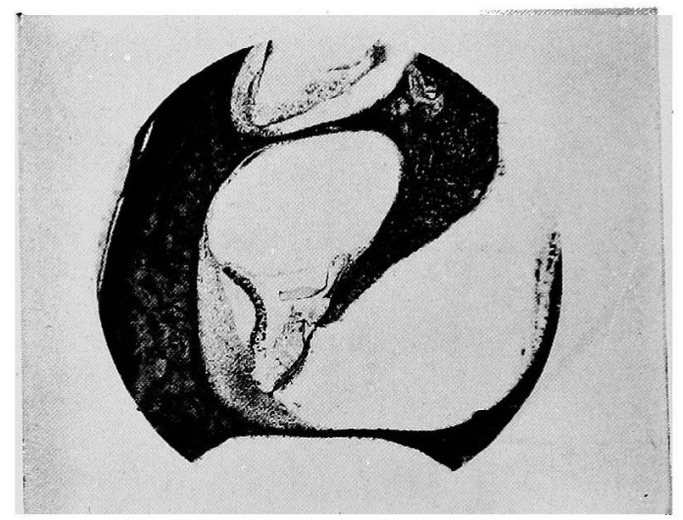




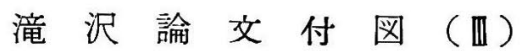

第 13 図

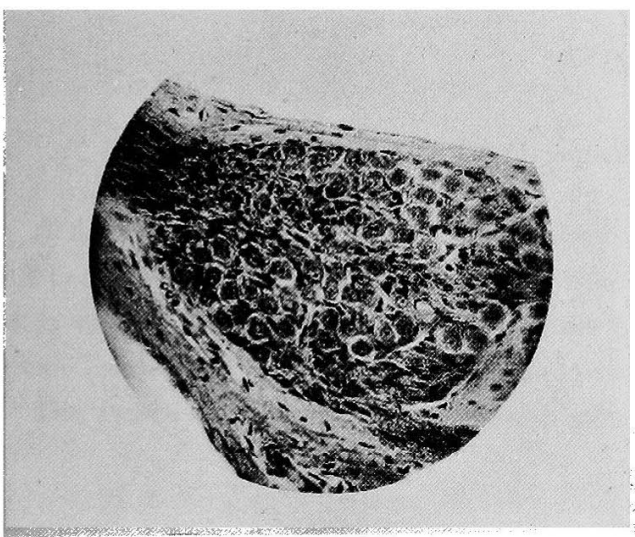

第 15 図

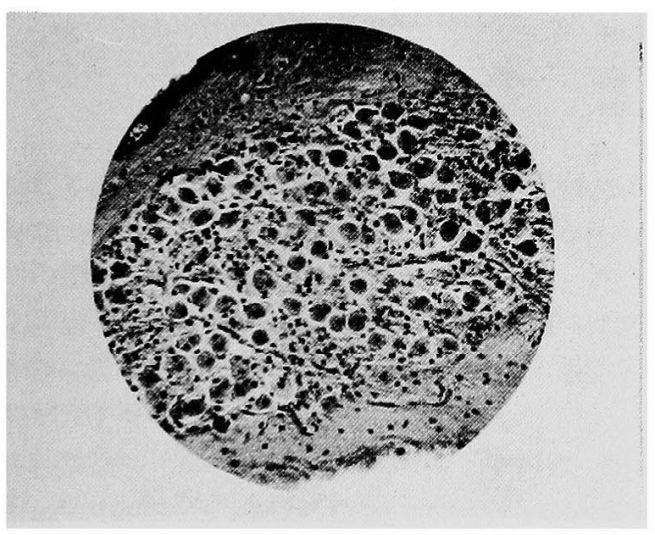

第 17 図

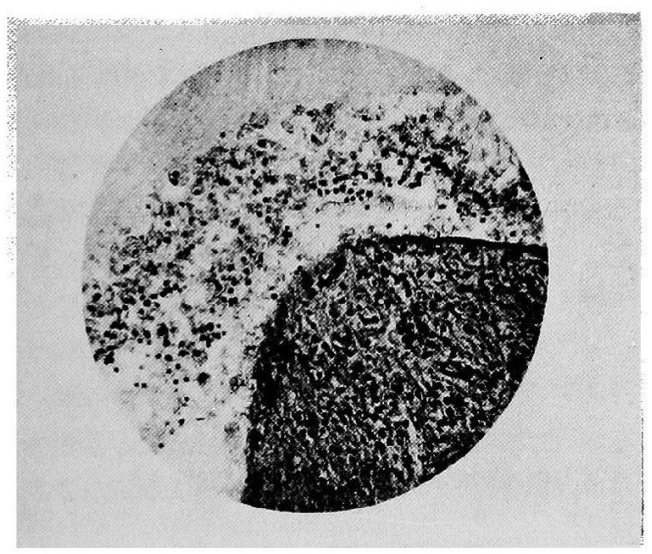

第 14 図

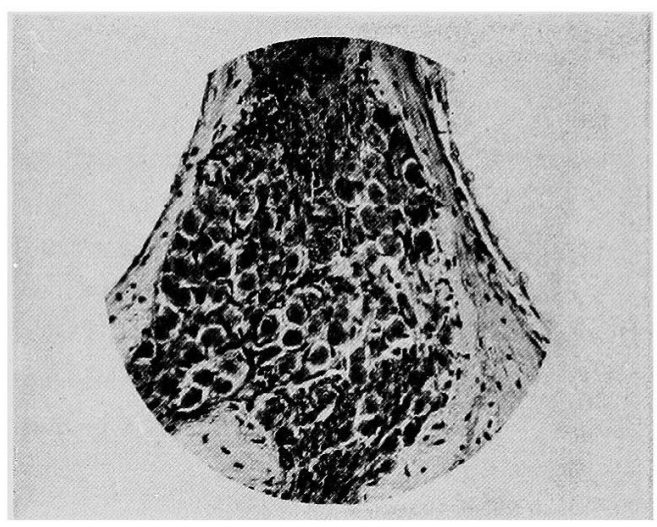

第 16 図

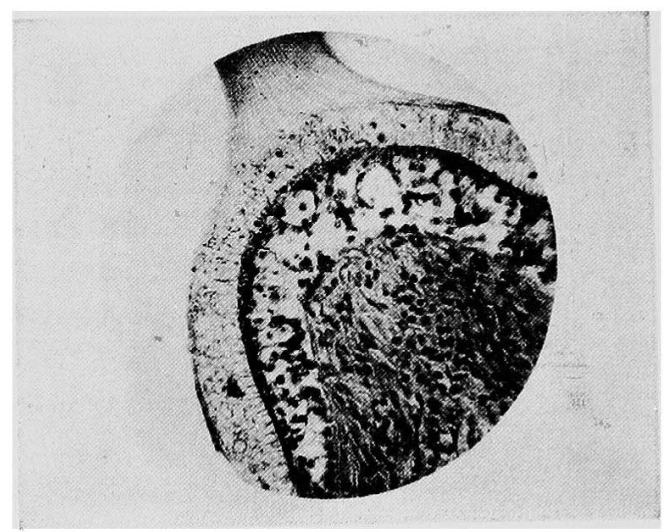

第 18 図

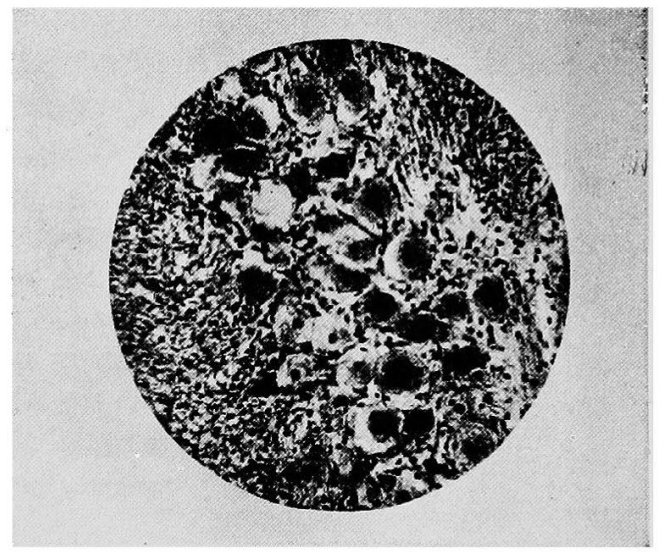

